Birmingham from 1948 until 1955, and head of the corresponding department in Imperial College from 1955 until 1962. He studied at Armstrong College (now University of Newcastle upon Tyne) from 1919 until 1922, and his early engineering experience was gained with Messrs. C. A. Parsons and with the Metropolitan Vickers Co. While with the latter Company he was responsible, among other developments, for the introduction of the form of electrical converter known as the metadyne and its application to electrical traction. During the Second World War he was concerned with automatic control as applied to automatic gun-laying, fuse-setting and gyroscope stabilization, and contributed greatly to the development of systematic methods of analysis of the behaviour of such feed-back systems, including the use of 'time series' and 'describing functions'. On the conclusion of the War he directed his attention to broader applications of the same ideas, especially in economies, and in his book The Mechanism of Economic Systems showed how economic instabilities may be understood in terms of the concepts developed by engineers. He also wrote D.C. Machines for Control Systems, giving the first systematic account of the class of machines, including the metadyne and amplidyne, now referred to as rotary amplifiers. He has published many papers on various aspects of electrical machines, notably on the sources of energy loss, heat-dissipation and rating, and commutation. He has been actively connected with the work of the Institution of Electrical Engineers, and in 1959-60 was chairman of the Measurement and Control Section. In 1953 Prof. Tustin was invited to occupy the Welster chair at the Massachusetts Institute of Technology as visiting professor. He had previously spent two years in the U.S.S.R. as an expert on machines for electric traction. Special mention should be made of his efforts to broaden the education of engineers by stimulating undergraduate interest in the economic and sociological aspects of engineering work. In Birmingham he initiated experiments that have since been developed into a very effective scheme within the engineering faculty as a whole, and at Imperial College he acted for many years as chairman of the Committee on General Studies. $\mathrm{He}$ is a man of unusually wide interests and his fertile brain will ensure that he does not lack absorbing problems in his retirement. He will be greatly missed by his colleagues in the Electrical Engineering Department at Imperia] College.

\section{Prof. E. R. Laithwaite}

DR. LaIthwaIte, who has been appointed to succeed Prof. A. Tustin, took first-class honours in electrical engineering at the University of Manchester, where he continued to M.Sc. in 1950 and Ph.D. in 1956. At the same time he was climbing the academic seale through assistant lecturer in 1950 and lecturer in 1953 to senior lecturer in 1957. Dr. Laithwaite's early research was concerned with specialized card-reading equipment for computer storage, but he retained an earlier interest in linear induction motors with the particular objective of adapting them to shuttle drive in looms. Among his early achievements in this field was the development of a switch-less reciprocating motor using two opposed linear motors. Later he participated actively in the development of various brush. less, variable-speed a.c. machines which had their origins in his linear induction machine, but retained his interest in linear machines and has continued work on their development for many industrial purposes such as electric traction, crane drive, slow-speed fans and so on. In addition to these research activities, he has developed exceptional qualities as a stimulating and onthusiastic lecturer. His election to the chair at the Imperial College of Science and Technology brings to an end about twenty years of continuous and fruitful association with the Department of Electrical Engineering in the University of Manchester, but marks the beginning of a new associa- tion carrying wider responsibilitios-Manchester's loss is London's gain.

\section{Radio Astronomy at the University of Manchester:} Prof. F. G. Smith

DR. F. G. Smith has been appointed a professor of radio astronomy in the University of Manchester, in succession to Prof. R. Hanbury Brown, who is now professor of physics (astronomy) in the University of Sydney. Dr. Smith was educated at the City of London Freemen's School, Ashtead, at Epsom College and at Rossall School. In 1941 he proceeded to Downing College, Cambridge, with a major scholarship but discontinued his studies in 1943 to enter scientific, war-time research at the Telecommunications Research Establishment, Malvern. In 1946 he returned to Downing College and took up his studies in the Natural Sciences Tripos, graduating in 1947 with a first-class honours degree in physies. From 1947 until 1951 he continued as a research student in astronomy at Cambridge and was awarded a Ph.D. in 1951. In the same year he was elected to the 1851 Senior Studentship and in the following year he was awarded an Imperial Chemical Industries fellowship. In 1954 he was appointed demonstrator in physics and later became a Fellow of Downing College and during 1958-59 he also served as a University proctor. In 1959 he was appointed Royal Society Warren observer in radio astronomy to work in the University of Cambridge. $\mathrm{He}$ has also served from 1958 until 1963 as a nember of the Council of the Royal Astronomical Society. Dr. Smith has worked in close co-operation with Prof. Ryle of Cambridge and has played a leading part in the development of teaching and research in radio astronomy in the University.

\section{Second Parliamentary and Scientific Conference}

THE second Parliamentary and Scientific Conference, organized jointly by the Council of Europe and the Organization for Economic Co-operation and Development, will be held in Vienna during May 23-27. The main objective of the Conference is "to give fresh impetus to the development of closer contacts between parliamentarians and scientists". Special attention will be directed to the progress made in the field of scientific policy making. The programme will include addresses by: Prof. G. Hess, president of the German Research Association (Federal Republie of Germany), entitled "Seience and Society"; Mr. Q. Hogg, Minister for Science (United Kingdom), entitled "Specific Present and Foreseeable Impacts of Science on Political Life"; M. G. Palewski, Minister for Scientific Research and Questions of Nuclear and Space Research (France), entitled "Importance of National and International Science Policies"; M. Karl Czernetz, Member of the Austrian Parliament, entitled "The Common Tasks of Parliamentarians and Scientists in Drawing up a Science Policy". The scientific delegates will be nominated by the Governments of all participating countries at the invitation of the Secretary General of the Organization for Economic Co-operation and Development. Further information can be obtained from the Organization for Economic Co-operation and Development, Chateau de la Muette, 2 rue Andre-Paseal, Paris 16e, France.

\section{Secretary of State for Education and Science}

The House of Commons on March 11 approved the Secretary of State for Education and Science Order, 1964. This establishes the new Secretaryship of State and the federal structure of his Department, transferring to him also the functions relating to the universities and University Grants Committee formerly discharged by the Treasury, as well as the functions of the Education Department and of the Office of the Minister for Science. In moving the motion, Mr. Q. Hogg explained that the reorganization of the Research Councils following the report of the Trend Committee would require an Act of 